\title{
土木，特にアスファルト舗装における熱画像解析の応用
}

\section{APPLICATION OF INFRARED SENSING ANALYSIS FOR CIVIL ENGINEERING}

\author{
森吉昭博* \\ By Akihiro MORIYOSHI
}

\begin{abstract}
This paper describes the infrared sensing analysis of asphaltic mixture and asphaltic pavement and presents the various application of infrared sensing analysis for civil engineering. In this study, it is concluded that surface temperature of asphaltic pavement depend upon the load of vehicle, materials of pavement components, climate of region and structure of pavement.
\end{abstract}

Keywords: infrared sensing analysis, surface temperature, asphaltic mixture, asphaltic pavement, civil engineering

\section{1. まえがき}

土木構造物や土木施工機械は厳しい自然環境の中で, 環境の変化に対応する材料で造られ，その材料は鋼，コ ンクリート，土およびアスファルトが主体となって単独 または複合材で構成されている。土木材料は比熱, 熱伝 導率，表面放射率，などの違いにより，表面からその材 料に応じた熱放射をする，化学プラント，電子産業，自 動車産業等は比較的簡易な熱画像撮影カメラで熱画像を 撮影し，この熱画像解析を利用する手法（以下これを簡 易な熱画像の方法という）を材料や工場の熱管理やエネ ルギー節約のために用いている ${ }^{1,2)}$. 舗装や土木施工機 械ではエネルギー節約や混合物の締め固め向上のために 温度計測はスポット的にかつ瞬間的に行われていだ). このため従来の方法は测定点が特異点かどうかの判定を することが難しく，情報も局部的で得られる情報量も少 なく, かつ土木構造物や材料の内部の状態を把握するこ とが困難であった．最近熱画像撮影力メラを用いて土木 構造物や土木施工機械で使用される材料について二次元 的かつ時系列的に材料の特性を把握しようとする動きが みられるようになった ${ }^{4), 5 !}$. 従来から人工衛星や飛行機

* 正会員 工博 北海道大学助教授 工学部土木工学科 ( ( 060 札幌市北区北 13 西 8)
によるリモートセンシング技術はこれと同様の性質を利 用して，国土のさまざまな情報を得ているが，この航空 機等を用いる方法は大気の補正等が必要で装置が大がか りで測定に膨大な費用を要していだ'。 これに対して簡 易な熱画像の方法は土木構造物に対して非接触で間接的 に時系列でかつ幅が $1 \mathrm{~mm}$ 以下で長さが $20 \sim 30 \mathrm{~cm}$ のよ うなクラックから幅が 2 $3 \mathrm{~cm}$ で長さが数 $\mathrm{km}$ にもわた るクラックに至るまでさまざまな状態が現地で観察がで き，構造物の表面温度分布からただちに構造物の内部の 状態も推定が可能である.このためこの簡易な熱画像の 方法は人工衛星からの情報と異なり直接構造物の材料の 性質が把握でき，そのデー夕を肉眼でも観察できるため 現場の状況を直ちに構造物の維持や施工管理に反映でき る. またこの簡易な熱画像の方法は道路構造物の一部で あるトンネル, 橋梁等のような長い構造物でもこのカメ ラを車上に登載することにより車を移動しながら短時間 にこれらの構造物の診断が交通規制なしで可能であり， 道路の陥没についても同様の診断が可能と思われる ${ }^{9)}$. 著者はこの簡易な熱画像の方法が表一1 に示すごとく土 木のさまざまな構造物に対して利用可能であると考え， その一部について測定を実施した。アスファルト舗装の この種の研究はアスファルト混合物の作成時から混合, 転圧, 供用時, 維持補修時に至るまで温度にして $300^{\circ} \mathrm{C}$ 
鯆积

\section{表一1 土木で考えられる熱画像解析の応用例}

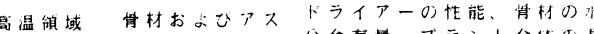
ファルトの加熱分含有量、ブラント全体の 度管理、アスフフルト加 熟タンク、慡水温度、フィ ルターバックの点模

混台物の混台トライアーの性能、ミキサー

の性能

通搬

数均

転圧 到着時の混合物の温度 フィニッシャーの保温、夕之 ハーの加如スクリートの的 却、混台物䧶搪け時の温度 分布、路盤温度

ローラの加熟、ローラ転忹時 の铺装温度(口-ラ種别)

目地部温度、混台物の治却 状況

铺装のヒータ適正温度、局部加热、加整 加整冷却特性

局部的補修混台物の温度、転压俊の治却 特性、铁筋配筧、シール効果 補修部の温度

常温㴭域車両走行

日射

ヒーティング

走行部の轨跡および温度

上昇、停止部およひ曲線部 の赤装温度、橋梁部の舗装 温度、夕イヤの温度

铺装の加熟冶却特性、白被

部の温度、すべりとめ部の 温度分布

效率、温度分布と铺装涅。

断热、断热材の効果

挢梁部

哺茈

低温領域铺装

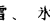

\begin{tabular}{|c|c|}
\hline トンネル & 坑門部 \\
\hline & 側㗎部 \\
\hline & $\begin{array}{l}\text { 頂部 } \\
\text { 铺装 }\end{array}$ \\
\hline のり面 & $\begin{array}{l}\text { モルタル部 } \\
\text { 一般部 }\end{array}$ \\
\hline
\end{tabular}

床板

标

タム

堤体部

水面

火力哞電

综子力発䉓

间 11

堤 防

流 ti

流等洴

石㣙備蓄

触雪树

铁道

軌 道
铺装の温度分布、ジョイン

卜部

莗裂、部の温度、切削

時の温度

盘裂部の空洞、幅、摩耗部

踭部の温度、スハイクタイ

ヤによる豧薪の温度、タイ

十の温度、凍上部、路局部

の温度、除賴溇の铺装温度

白缐の摩耗、断熟材の効

果、マンホール付近、雨水

树の涷祮

温度分布、虽雪剂の效果。

夕イヤによる融筜、信步栍

の温度分布による剈第、信

岇機の温度分布

コンクリートの电裂、濑水

と凍袺、裹这め効果

空洞、断熱材の効果、铁荕

の位狊、排水湭の淉結

裹込め効果

ヒーティンク効果、渓水㳻

空洞、电裂

地消り

コンクリートの电裂、打

杭の温度

コンクリートの电裂、ヒ一

ティング就果、鉄筋の落接

クースアスファルト!るよ

然ひずみ、塣装の刺離

リヘッ卜、溶接筬所の教贺

化

コンクリート部の老化、电

裂、マスコンクリートの温

度卜算

隶の热応力推定、水の㫣裂

水温分布(取水制御) 、水

筫管理

治却水、㩐管理

治却水、放水温度( 温度管

理 )

瓨水、湿潤筒所調查

表面温度分布(流速分布

流砂量分布)

彗混入水の温度(投入量制 限)

制の溶接、鋮板のひず

水温、コンクリート部材

水温

レールの溶接、架線のス八

一ク、フレーキ温度、雪や

氷の付着、融鳖、ホイント

のヒ一夕、寒泠地用車車

通通時のレールの混度
から $-40^{\circ} \mathrm{C}$ 程度まで幅広い温度領域が対象となると考 えられる.トンネル, ダム, 河川, 発電所等は対象亡な る構造物の温度幅が常温領域から低温領域亡比較的狭い ものの，このような構造物は構造物の安全性の面から熱 画像解析を行う研究が望まれていると考えられる.また 土木施工機械は除雪車のようにー $20^{\circ} \mathrm{C}$ 以下からアス ファルト舗装施工機械のように $150^{\circ} \mathrm{C}$ 以上の温度にさ らされるため施工機械にもいろいろな温度トラブルが生 じる.このような土木分野はこの簡易な熱画像の方法の 応用が望まれる. 本研究はアスファルト舗装で特に低温 領域の亀裂䇢所の特定化およびその損傷の程度ならびに ホイールトラッキング試験におけるアスファルト混合物 の供試体の走行車両による温度上并について検討した結 果のみについて報告する。

\section{2. 測定法および測定簓所}

使用した 3 種類の熱画像撮影カメラの主な仕様は表一 2 のとおりである.

野外の測定はワゴン車の内部から熱画像撮影カメラを 手持ちの状態で路肩部を約 $15 \mathrm{~km} / \mathrm{h}$ の速度で走行しな がら，走行車線のほぼ一車線分を水平方向から約 30 度 下に向けて撮影し, 器械本体の過度の冷却を避けながら 行った．測定箇所は北海道縦貫自動車道千歳～苫小牧間 とし，測定は外気温がいずれも $-5^{\circ} \mathrm{C}$ のときで舗装路面 上に雪のない状態で行った，北海道縦貫自動車道の測定 箇所は寒冷期に熱応力により生ずるアスファルト舗装の 横断亀裂現象が著しい区間である。熱画像解析は撮影し た熱画像をビデオテープに撮りこの画像のデー夕を用い て行った。 そのとき舗装表面温度は熱画像収録時にアス ファルト舗装の放射率は 1.0 の一定值とし，この值から 求めたので数值は絶対温度ではなく相対温度と考え た . 舖装の表面温度は接触型の温度計で確認したとこ ろこの相対温度とほぼ対応していることが確認されてい る.

実験室の温度測定はホイールトラッキング試験中にア スファルト混合物の供試体の表面を熱画像撮影カメラで 水平方向から約 45 度下に傾けた状態で行った。実験は

\begin{tabular}{|c|c|c|c|}
\hline \multirow[t]{2}{*}{ 表一2 } & \multicolumn{3}{|c|}{ 熱画像撮影カメラの主な性状 } \\
\hline & $\begin{array}{l}\text { インフラ } \\
\text { メトリックス (株) }\end{array}$ & 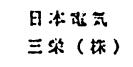 & $\begin{array}{l}\text { 日本アヒォ } \\
\text { ニタス(标) }\end{array}$ \\
\hline 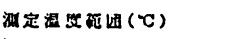 & $-20 \sim 1300$ & $-20 \sim 1600$ & $-10 \sim 200$ \\
\hline 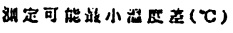 & 0.1 & 0.1 & 0.1 \\
\hline 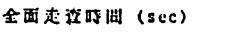 & $1 / 60$ & 2 & $1 / 20$ \\
\hline 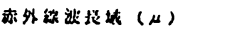 & $8 \sim 12$ & $3.5 \sim 5.6$ & $3 \sim 5.1$ \\
\hline 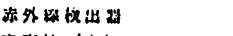 & HxCdTe & Ins. & Ins. \\
\hline 走证私（本） & 200 & 230 & 60 \\
\hline 法示相数 & $256 \times 200$ & $512 \times 210$ & $256 \times 120$ \\
\hline
\end{tabular}


密粒度アスファルトコンクリート(バインダー量 $5.8 \%$ ) タイプの混合物を用いた。.アスファルト混合物の混合は アスファルトの粘度が 2 ポアズ $\left(0.2 \mathrm{Ns} / \mathrm{m}^{2}\right)$ の温度の ときとし，転圧はこれをアスファルトの粘度が 30 ポア ズ $\left(3 \mathrm{Ns} / \mathrm{m}^{2}\right)$ の温度のとき $30 \times 30 \times 5 \mathrm{~cm}$ の鋼製型枠 の中に投入し，ローラーコンパクタを用い，線圧 18 $\mathrm{kgf} / \mathrm{cm}(176.4 \mathrm{~N} / \mathrm{cm})$ で 24 回行った. その後ホイー ルトラッキング試験はこの供試体を用いて $45^{\circ} \mathrm{C}$ の部屋 の中で接地圧 $5.5 \mathrm{kgf} / \mathrm{cm}^{2}(0.54 \mathrm{MPa})$ ，トラッキング 速度 42 回/分の状態で行った。このとき供試体内部の温 度計測は埋め込まれた熱電対で行うとともに, 供試体表 面の温度は熱画像撮影カメラを用いて計測した8.

\section{3. 結果および考察}

\section{（1） 低温時の舗装表面の温度分布}

表一3 は赤外線放射温度計で撮影した画面の中央部水 平線上の舗装表面温度をほぼ 2 秒ごとに平均し，この温 度を一画面の平均温度とし，この操作を繰り返し数百 $\mathrm{m}$ ごとにほぼ同一時間に撮影した結果を区間の平均温 度とした。撮影にあたり横断亀裂の多少等により区間を 分け，日射の影響は十分考虑した。アアスファルト舗装の 表層材は密粒度アスファルトコンクリートで粒度，アス ファルト量とも全区間ほぼ同一である. 表面の温度がこ のように異なるのは同一路線でも切土区間, 盛土区間が あるだけでなく地下水位の高さ，気象条件や使用してい

\begin{tabular}{ccc} 
表一3 & \multicolumn{3}{c}{ 区間ごとの舗装表面の平均温度 $\left({ }^{\circ} \mathrm{C}\right)$} \\
\cline { 2 - 3 } $\begin{array}{c}\text { 区间長 } \\
(\mathrm{m})\end{array}$ & $\begin{array}{c}\text { 平均温度 } \\
\left({ }^{\circ} \mathrm{C}\right)\end{array}$ & $\begin{array}{c}\text { 琶裂本数 } \\
(\text { 本 })\end{array}$ \\
\hline 1000 & 1.3 & 9 \\
900 & 1.3 & 0 \\
800 & -0.3 & 0 \\
900 & -0.1 & 0 \\
700 & -2.3 & 7 \\
\hline
\end{tabular}

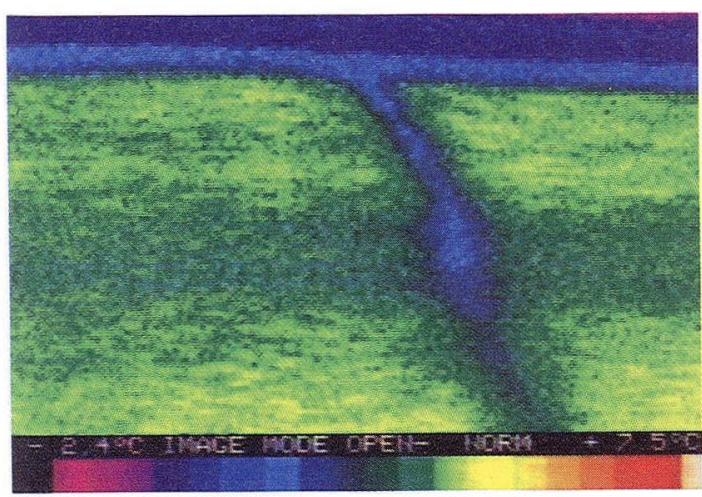

写真一 1 横断白裂部付近の温度分布
る材料の熱的性状等が微妙に異なるためと思われる.ア スファルト舗装の横断亀裂現象は舗装温度が $2 \sim 3^{\circ} \mathrm{C}$ 異 なるだけでも破壞形態が異なることが知られているの で，このような区間温度の差はこの現象に大きな影響を 与えていると考えられる.

写真一 1 は横断亀裂部の温度分布を示す。この箇所は 一般の舗装部と比較してこの場合 $2.5^{\circ} \mathrm{C}$ 低くなってい る. 写真一1において目で観察される斜め方向に走る一 様な亀裂幅 (幅約 $1 \mathrm{~cm}$ ) と赤外線放射温度計で測定さ れた横方向にみえる白線（幅約 $15 \mathrm{~cm}$ ) や斜め方向に走 る亀裂部の低温帯 $(10 \sim 20 \mathrm{~cm})$ から判断して亀裂部の 低温の幅が異なるのは亀裂内部の状況等により, 亀裂部 の冷却特性が正常部と比較して異なるためと考えられ $3^{99}$.

\section{（2） アスファルト混合物の供試体の温度測定}

ホイールトラッキング試験中, アスファルト混合物の 表面から深さ $5 \mathrm{~cm}$ までのすべての箇所の温度は時間経 過とともに上昇する ${ }^{10)}$. これを熱画像撮影カメラで表面 を撮影すると写真一2の結果が得られた。この画面の温 度スケールは 35.0 から $41.4^{\circ} \mathrm{C}$ まで $0.4^{\circ} \mathrm{C}$ 刻みで 16 階 調とした。

実験の初期の状態はアスファルト混合物の表面温度が 同一なためすべて水色の約 $37^{\circ} \mathrm{C}$ の一定值なのに対し て, 20 分経過後では夕イヤ接地部分のみならず付近の 混合物やソリッドタイヤまで温度が上昇している．ここ で中央カーソルの交点の温度は $38.4^{\circ} \mathrm{C}$ で中央部水平線 部の温度分布は下部の折れ線グラフで示す．ここでは 1 目盛が $1.6^{\circ} \mathrm{C}$ であることから，特に供試体表面中央部 が他の部分より 20 分経過で約 $2^{\circ} \mathrm{C}$ 程度高くなっている ことがわかる，供試体中央部表面の温度を接触型の表面 温度計で測定した結果もこの結果と対応することが確認 されている. 夏期においても特に車両走行軌跡部付近の 舗装表面温度の上昇が著しい。このようなアスファルト 舗装の表面温度の上昇はアスファルト舗装の波うちやわ

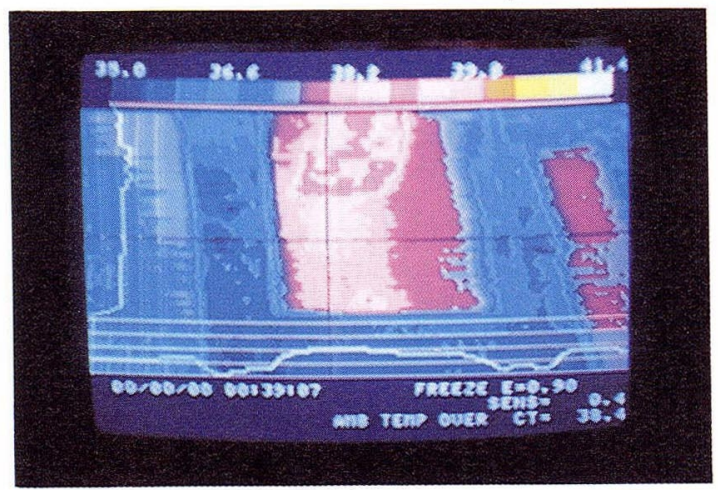

写真一2 ホイールトラッキング試験の温度分布 (20 分後) 
だち掘れ現象と密接な関係があると思われる。この実験 でソリッドタイヤの幅が $5 \mathrm{~cm}$ にもかかわらずタイヤ付 近の供試体の温度が上昇するのは繰り返し荷重によりア スファルト混合物が粘弾性体のため応力ーひずみ曲線が ヒステリシスループを描き, このループ内の面積相当の エネルギーが熱として外部に放散されること，また夕イ ヤと供試体表面との摩擦熱が主な原因と思われる。

\section{4. まとめ}

以上で述べたことをまとめると次のようである.

（1）アスファルト舗装で赤外線放射温度計は低温の 横断亀裂現象の評価から比較的高温領域の車両走行に伴 う舗装の温度分布まで測定可能と思われる.

（2）非接触の赤外線放射温度計は土木構造物の評価 や診断に手軽に利用できるように思われる.

本研究は表一1 に示すような土木において簡易な熱画 像の方法の応用例が数多く考えられるが，ここではごく 一部の例を示したにすぎない。この研究は緒についたば かりなのでまだ十分とはいいがたい。特に常温以下の温 度測定は機械の性能からカメラの角度, 温度刻み, 測定 条件等考慮すべき点が多い. 読者の皆様のご意見, ご叱 責をいただければ幸いです。

アスファルト舗装の亀裂の幅, 深さおよび亀裂内部の 空洞の診断は現在低温のメタノールをアスファルト亀裂 に注入し，熱画像撮影カメラで撮影することも考えてい る.この分野の研究がこれからますます盛んになること を希望します。

謝辞：本研究は北海道クリアパルス (株), 日本 電気三栄 (株) 札幌支店および日本アビオニクス（株） から熱画像撮影装置一式をお借りし，これらの器械を用
いて種々の対象物の熱分布を計測した. 舖装表面の温度 は測定するにあたり日本道路公団札幌建設局の方々に， 一方熱画像解析においては本学電気工学科 深井一郎教 授，榎戸武揚助教授に大変お世話になった。 また河川， 発電関係の応用例は本学土木工学科 長谷川和義博士の 考えに沿ったものである. 関係の皆様方にここに感謝致 します。

\section{参 考 文 献}

1）日本写真測量学会編：熱赤外線りモートセンシングの技 術と実際, 鹿島出版会, 1986 年 11 月.

2）渡辺比佐雄 : 赤外線放射を利用した測温装置の応用実例 について，画像技術，1972 年 9 月.

3）アスファルト舗装要網：(社) 日本道路協会.

4）森吉昭博・深井一郎・榎戸武揚：アスファルト舗装の横 断ひびわれ現象の温度解析, 第 17 回日本道路会議一般論 文集, pp. $435 \sim 436$, 昭和 62 年.

5）森吉昭博・深井一郎・榎戸武揚：低温時における赤外放 射温度計によるアスファルト舗装の温度計測, 寒地技術 シンポジウム '87 講演論文集, pp. 135 137，1987 年 11 月.

6) P. Ruiz-Azuara : Detecting Hydrobiological Parameters with LANDSAT 3 Summer 1981 Data, The ERIM Nineteenth International Symposium on Remote Sensing of Environment, October 21-25, 1985.

7) 5) ibid.

8）新田 登・森吉昭博・高橋 将：繰り返し走行荷重下に おけるアスファルト混合物の温度変化, 第 17 回日本道路 会議一般論文集, pp. 326 327, 昭和 62 年.

9）田代徽雄・日裏 徹・青柳志郎：赤外線熱画像装置を用 いたシミュレイションによる建築物の熱的, 構造的特性 の解析システム, 寒地技術シンポジウム'85 講演論文集, pp. $65 \sim 70,1985$ 年 11 月.

10) 8) ibid

（1989.3.31 ·受付） 